\title{
Errors, near misses and adverse events in the emergency department: What can patients tell us?
}

\author{
Steven M. Friedman, MD, MPH; David Provan, BA, MA; Shannon Moore, BSc, MSc; \\ Kate Hanneman, BSc
}

\begin{abstract}
Objective: We sought to determine whether patients or their families could identify adverse events in the emergency department (ED), to characterize patient reports of errors and to compare patient reports to events recorded by health care providers.

Methods: This was a prospective cohort study in a quaternary care inner city teaching hospital with approximately 40000 annual visits. ED patients were recruited for participation in a standardized interview within 24 hours of ED discharge and a follow-up interview 3-7 days after discharge. Responses regarding events were tabulated and compared with physician and nurse notations in the medical record and hospital event reporting system.

Results: Of 292 eligible patients, 201 (69\%) were interviewed within 24 hours of ED discharge, and 143 ( $71 \%$ of interviewees) underwent a follow-up interview 3-7 days after discharge. Interviewees did not differ from the base ED population in terms of age, sex or language. Analysis of patient interviews identified 10 adverse events (5\% incident rate; $95 \%$ confidence interval $[\mathrm{Cl}]$ $2.41 \%-8.96 \%$ ), 8 near misses ( $4 \%$ incident rate; $95 \% \mathrm{Cl} 1.73 \%-7.69 \%$ ) and no medical errors. Of the 10 adverse events, $6(60 \%)$ were characterized as preventable ( 2 raters; $\kappa=0.78$, standard error [SE] $0.20 ; 95 \% \mathrm{Cl} 0.39-1.00 ; p=0.01)$. Adverse events were primarily related to delayed or inadequate analgesia. Only 4 out of $8(50 \%)$ near misses were intercepted by hospital personnel. The secondary interview elicited 2 out of 10 adverse events and 3 out of 8 near misses that had not been identified in the primary interview. No designation ( 0 out of 10 ) of an adverse event was recorded in the ED medical record or in the confidential hospital event reporting system.

Conclusion: ED patients can identify adverse events affecting their care. Moreover, many of these events are not recorded in the medical record. Engaging patients and their family members in identification of errors may enhance patient safety.
\end{abstract}

Keywords: errors, near miss, adverse events, emergency, patient, patient safety

RÉSUMÉ

Objectif : Nous avons cherché à déterminer si les patients ou leurs familles pouvaient détecter des événements indésirables à l'urgence, à caractériser les rapports d'erreurs des patients et à comparer les rapports des patients aux événements consignés par les fournisseurs de soins de santé.

Méthodes : Nous avons réalisé une étude de cohorte prospective dans un hôpital universitaire de soins quaternaires du centre-ville qui compte environ 40000 visites annuellement. Nous avons recruté des patients à l'urgence pour participer à une entrevue normalisée dans les 24 heures suivant 
leur congé de l'urgence ainsi qu'à une entrevue de suivi réalisée trois à sept jours après leur congé. Les réponses concernant les événements indésirables ont été classées et comparées aux notes des médecins et des infirmières dans le dossier médical et le système de déclaration des incidents de I'hôpital.

Résultats : Des 292 patients admissibles à l'étude, 201 (69\%) ont été interviewés dans les 24 heures suivant leur congé de l'urgence, et 143 (71\% des personnes interrogées) ont pris part à une entrevue de suivi entre trois et sept jours après avoir obtenu leur congé. Le profil des personnes interrogées était semblable à celui de la population de base en ce qui concerne l'âge, le sexe ou la langue. L'analyse des entrevues avec les patients a permis de relever dix événements indésirables [taux d'incidence de $5 \%$; intervalle de confiance (IC) à $95 \%, 2,41$ à 8,96 \%], huit quasi-accidents (taux d'incidence de $4 \%$; IC à $95 \%, 1,73$ à 7,69 \%) et aucune erreur médicale. Des dix événements indésirables, six $(60 \%)$ ont été caractérisés comme étant évitables [deux évaluateurs; $\kappa=0,78$, erreur-type (ET) à 0,20, IC à $95 \%, 0,39$ à 1,00, $p=0,01$ ]. Les événements indésirables étaient principalement liés à un retard d'administration d'analgésique ou à une analgésie inadéquate. Seulement quatre des huit quasi-accidents $(50 \%)$ ont été interceptés par le personnel hospitalier. La deuxième entrevue a permis de découvrir deux des dix événements indésirables et trois des huit quasi-accidents qui n'avaient pas été relevés lors de la première entrevue. Aucun événement indésirable ( 0 sur 10 ) n'avait été consigné dans le dossier médical de l'urgence ou dans le système confidentiel de déclarations d'incidents.

Conclusion : Les patients à l'urgence peuvent détecter des événements indésirables ayant une incidence sur leurs soins. En outre, bon nombre de ces événements ne sont pas consignés dans le dossier médical. On peut améliorer la sécurité des patients si l'on encourage les patients et les membres de leur famille à détecter les erreurs.

\section{Introduction}

Emergency departments (EDs) worldwide are increasingly characterized as high-volume, high-pressure environments that are experiencing shortages of skilled medical staff, beds and support services. Even at times of low volume, the ED is prone to error. There is little automation, little consistency, little task standardization, few forced functions, questionable team coordination, high variability and frequent interruption. ${ }^{1}$ Efforts to increase identification and analysis of errors in hospitals have included campaigns that are geared toward establishing safety awareness, mandatory reporting policies and anonymous error reports in a shift away from blaming individuals.

Patients and their family members may be able to observe errors and adverse events that go unnoticed or unreported by health care providers. Family members often have a detailed knowledge of the patient's medical needs and functional status and spend more time at the bedside than the doctor or nurse. However, there is a limited body of research looking to patients and their family members as a resource for quality improvement. Weingart and colleagues ${ }^{2}$ conducted a prospective study interviewing 228 adult inpatients on a medicine unit of a Boston teaching hospital. Eight percent of patients experienced adverse events and 4\% experienced near misses. Approximately one-half of the adverse events and one-third of the near misses were documented in the medical records, but none were found in the hospital event reporting system. Forster and colleagues ${ }^{3}$ and Forster and coauthors ${ }^{4}$ used telephone follow-up to measure the incidence of adverse events occurring after discharge. Follow-up of 400 consecutive patients discharged from a general medicine ward revealed 76 adverse events in the 2-week follow-up period, of which 23 were classified as preventable and 24 as ameliorable. All of the preventable and ameliorable adverse events were associated with 1 or more deficiencies in system design. In a multicentre series of interviews of patients discharged from the ED, the majority of ED patients indicated feeling relatively safe from medical errors, yet a significant percentage of patients expressed concern about a specific error during their ED encounter. ${ }^{5}$ Only 1 previous study prospectively evaluated adverse events in patients discharged home from the ED. Two-week telephone follow-up of approximately 400 patients revealed a $6 \%$ incidence of adverse events, of which $63 \%$ led to an additional ED visit or hospitalization. Common problems included errors in management or diagnosis, and unsafe disposition decisions. ${ }^{6}$ These studies all suggest that telephone follow-up after discharge is a successful method of identifying errors not otherwise found.

We undertook a prospective cohort study to determine whether patients and their family members could identify adverse events and near misses in the ED environment. 
Secondary goals were to stratify these errors by process and to compare events identified with those recorded in the ED record and hospital event reporting database by physicians and nurses.

\section{Methods}

We conducted our study at the ED of the Toronto Western Hospital, a quaternary care inner city teaching hospital with approximately 40000 annual visits. The ED is situated in an ethnically diverse community with immigrants from China, Portugal and Latin America. The study population consisted of a convenience sample of patients who attended the ED and were not admitted to hospital. Data were collected during 12 six-hour periods between February and April 2005. Data collection periods included day, evening and overnight shifts from both weekdays and weekends, were not structured to correspond with emergency physician shift start and finish times, and were scheduled without knowledge of which emergency physician would be on duty at any time. This study was approved by the hospital's Research Ethics Board.

ED patients were recruited for participation in a standardized interview within 0-24 hours of ED discharge and a follow-up interview 3-7 days after discharge. Interviews were done by trained medical students, and emergency physicians were not informed of when the interviewers were recruiting patients outside the ED. Patients were not informed of the nature of the interviews at the time of recruitment. Responses regarding events were characterized and compared with physician and nurse notations in the medical record and the hospital event reporting database.

Patients were included if they were ambulatory, mentally competent, 18 years of age or older, not admitted to hospital and able to provide informed consent by themselves or through an accompanying English-speaking translator. Patients were excluded from the study if they were nonambulatory, incapable of providing informed consent because of a language barrier or impaired mental status, under the age of 18 years, intoxicated or in police custody.

\section{Patient interviews}

Patients who consented to participate were recruited for a primary telephone interview within 24 hours of ED discharge. The medical students who administered the survey (S.M. and D.P.) read from a form that was preprinted with the interview text and included space for the interviewer to transcribe responses. The patients were asked 4 standard, previously validated interview questions ${ }^{2}$ about their experience in the ED:
1. Do you believe that there have been any problems with your care during your stay in the emergency department?

2. Do you believe that you were hurt during your stay in the emergency department?

3. Do you believe that you stayed in the emergency department too long because of problems with your care?

4. Do you believe that anyone made a mistake that affected your care during your stay in the emergency department?

Patients who answered "yes" to any of these interview questions were asked scripted open-ended questions (e.g., "If yes, please specify..."; "What kind of mistake was made?"; and "Please indicate if you know why you stayed longer in hospital") that encouraged further details about the incident. Patient responses were transcribed by hand. Demographic data were elicited at the interview and also abstracted from the ED chart.

A follow-up telephone call was made between 72 hours and 1 week following the ED visit. Patients were asked, "Since being discharged from the emergency department a few days ago, do you believe that there have been any further problems with your care relating to your visit to the emergency department?" Patients who answered in the affirmative were asked, "Please specify what problem or problems have occurred since your discharge from the emergency department."

\section{Review of ED chart and institutional database}

The ED chart of each patient interviewed was reviewed in a standardized manner by one of the interviewers for documentation of errors, near misses and adverse events by health care staff that may have been identified by health care providers or by the patient or family upon interview. The hospital patient and visitor incident database was reviewed in cases where events were documented in the medical record by health care providers or described by the patient or family member in the follow-up interview.

\section{Categorization of errors}

Upon completion of the data collection, an ED physician examined the incidents reported in primary and secondary patient interviews and categorized the data using previously established defined criteria, including "adverse event," "near miss" and "medical error." The definitions used were as follows:

- Adverse event: unintended injury or complication caused by health care management rather than the patient's underlying disease.

- Near miss: potential adverse event that was identified before it caused harm to the patient. 
- Medical error: a mistake that did not adversely affect the health of the patient.

Events were further classified by severity and by process of care, using a previously published system. ${ }^{2,7}$ Adverse events were rated as "preventable" or "not preventable" by 2 independent, blinded emergency physicians. In the event of a disagreement, a third physician provided a blinded evaluation.

\section{Results}

The researchers approached 348 patients for participation. Of those, 56 were excluded because they were under 18 years of age, intoxicated, or unable to communicate in English and lacked an accompanying translator. Of the 292 eligible patients, $201(69 \%)$ were interviewed within 24 hours of ED discharge and 143 (71\% of those who underwent primary interview) underwent a follow-up interview 3-7 days after discharge. A description of the interviewees and comparison of some demographic data with the case ED population is shown in Table 1. The interviewees did not differ from the base ED population in terms of age, sex or language.

\section{Errors, adverse events and near misses}

Patient interviews identified 10 adverse events (5\%; 95\% confidence interval [CI] 2.41\%-8.96\%), 8 near misses (4\%; 95\% CI 1.73\%-7.69\%) and no medical errors among 18 unique patients.

\section{Adverse events}

Numbers of adverse events and a narrative description of each are shown in Table 2. Ten adverse events were noted (5\% incident rate). None were deemed serious or lifethreatening. One-half of these were related to analgesia management. None of these events were recorded by the nurse or physician in the ED record, and no events were recorded in the hospital event reporting database. Six of the $10(60 \%)$ adverse events were characterized as preventable ( 2 raters; $\kappa=0.78$, standard error 0.20 ; $95 \% \mathrm{CI}$ $0.39-1.00 ; p=0.01)$.

\section{Near misses}

Near misses were identified in 8 of 201 (4\%) patient interviews. While most were minor, 1 involved prescription of a medication (codeine) to which the patient had previously suffered a serious allergic reaction. One-half of the near misses (4 out of 8 ) were not recognized by hospital staff (physician, nurse or pharmacist). Only 1 near miss (prescription of medication to known allergic patient) was ultimately recorded on the medical record, and no near miss was recorded in the hospital event recording database.

\section{Medical errors}

No medical errors were identified by patients or their family members.

\section{Analysis by process of care and practitioner}

Table 3 shows a breakdown of the described events by process of care. Most adverse events were clustered around pain management.

\section{Discussion}

Our small Canadian pilot study showed that telephone interviews with discharged ED patients and their families can identify adverse events and near misses that would otherwise go unrecognized. Although few serious adverse events were identified, most that were identified were preventable. Moreover, the methodology was helpful in identifying a process of care as potentially deficient. This is only the second published study that we have found that interviewed patients and their family members after discharge from the ED in order to glean information about adverse events, errors and near misses.

Table 1. Study versus ED population demographics

\begin{tabular}{|c|c|c|}
\hline \multirow[b]{2}{*}{ Variable } & \multicolumn{2}{|c|}{ Group; no. (and \%)* } \\
\hline & $\begin{array}{c}\text { Study } \\
\text { population; } \\
n=201\end{array}$ & $\begin{array}{l}\text { Base ambulatory } \\
\text { ED population, } \\
\text { during the year } \\
\text { of study; } \\
n=29425\end{array}$ \\
\hline Mean (and median) age, yr & $44(42)$ & $46(42)$ \\
\hline \multicolumn{3}{|l|}{ Sex } \\
\hline Female & 52.7 & 48.5 \\
\hline Male & 47.3 & 51.5 \\
\hline $\begin{array}{l}\text { First language other than } \\
\text { English }\end{array}$ & $95(47.3)$ & $(48.9)$ \\
\hline Interpreter required & $14(7.0)$ & (8.8) \\
\hline Mean (and range) CTAS score & $3.7(2-58)$ & - \\
\hline \multicolumn{3}{|l|}{ General health (self rating) $\dagger$} \\
\hline Excellent or very good & $77(38.5)$ & - \\
\hline Good & $92(46.0)$ & - \\
\hline Fair or poor & $31(15.5)$ & - \\
\hline \multicolumn{3}{|l|}{$\begin{array}{l}\text { Patient had a family doctor } \\
\text { or regular clinict }\end{array}$} \\
\hline Yes & $170(85.0)$ & - \\
\hline No & $30(15.0)$ & - \\
\hline \multicolumn{3}{|c|}{$\begin{array}{l}\text { CTAS }=\text { Canadian Emergency Department Triage and Acuity Scale; } \\
\text { ED = emergency department. } \\
* \text { Unless otherwise indicated. } \\
\text { t } n=200 \text { because } 1 \text { patient did not provide this information at the interview. }\end{array}$} \\
\hline
\end{tabular}


Most adverse events centred around a single process of care: pain management. The Joint Commission on Accreditation of Healthcare Organizations has made assessment and management of pain a quality standard on which hos- pitals are judged. ${ }^{8}$ ED crowding is associated with poor quality of care in patients who have severe pain, with respect to total lack of treatment and delay until treatment. ${ }^{9}$

Few events that were identified by patients and family

Table 2. Adverse events and near misses in study participants

\begin{tabular}{|c|c|c|c|}
\hline Severity & $\begin{array}{l}\text { No. (and \%) of } \\
\text { adverse events }\end{array}$ & Event & Rated preventable* \\
\hline \multicolumn{4}{|l|}{ Adverse events } \\
\hline $\begin{array}{l}\text { 1. Life-threatening, } \\
\text { e.g., anaphylaxis }\end{array}$ & $0(0.0)$ & - & - \\
\hline $\begin{array}{l}\text { 2. Serious, } \\
\text { e.g., large abscess }\end{array}$ & $0(0.0)$ & - & - \\
\hline \multirow[t]{8}{*}{$\begin{array}{l}\text { 3. Significant, } \\
\text { e.g., pain, diarrhea }\end{array}$} & $8(4.0)$ & $\begin{array}{l}\text { - } 50 \text {-yr-old man, abscess, delayed analgesia after patient } \\
\text { request }\end{array}$ & Y \\
\hline & & $\begin{array}{l}\text { - 34-yr-old man, crush or fracture of } 2 \text { fingers, delayed } \\
\text { analgesia after patient request }\end{array}$ & Y \\
\hline & & $\begin{array}{l}\text {-29-yr-old man, fell } 5 \text { feet, shoulder, wrist, knee injury; no } \\
\text { fracture, delayed analgesia after patient request }\end{array}$ & Y \\
\hline & & $\begin{array}{l}\text { 73-yr-old woman, ankle inversion, lateral malleolus fracture, } \\
\text { delayed analgesia after patient request }\end{array}$ & Y \\
\hline & & $\begin{array}{l}\text { - 50-yr-old woman, wrist fracture, delayed analgesia after } \\
\text { patient request }\end{array}$ & Y \\
\hline & & $\begin{array}{l}\text { - } 19-y r-o l d \text { woman, pain in left lower quadrant and low back, } \\
\text { poor response to } 2 \text { pain medications }\end{array}$ & $\mathrm{N}$ \\
\hline & & $\begin{array}{l}\text { - } 45 \text {-yr-old man, oncology patient, requested but did not } \\
\text { receive urinal, fell on way to bathroom alone, pain, bruising }\end{array}$ & Y \\
\hline & & $\begin{array}{l}\text { - 33-yr-old man, wrist injury, splint felt tight, removed several } \\
\text { days later at hand clinic }\end{array}$ & $\mathrm{N}$ \\
\hline \multirow{2}{*}{$\begin{array}{l}\text { 4. Moderate, } \\
\text { e.g. discomfort or } \\
\text { inconvenience for } \\
1-24 \mathrm{~h}\end{array}$} & $2(1.0)$ & $\begin{array}{l}\text { - 49-yr-old woman, oncology patient, intravenous line removal } \\
\text { "tears skin," prolonged oozing }\end{array}$ & $\mathrm{N}$ \\
\hline & & $\begin{array}{l}\text { - 62-yr-old man presented to ED with epistaxis, discharged } \\
\text { without intervention causing rebleeding }\end{array}$ & $\mathrm{N}$ \\
\hline $\begin{array}{l}\text { 5. Minor, } \\
\text { discomfort or } \\
\text { inconvenience for } \\
\text { for }<1 \mathrm{~h}\end{array}$ & $0(0.0)$ & - & - \\
\hline \multicolumn{4}{|l|}{ Near misses } \\
\hline $\begin{array}{l}\text { 1. Life-threatening, } \\
\text { e.g., anaphylaxis }\end{array}$ & $1(0.0)$ & - Prescribed codeine, known serious codeine allergy & - \\
\hline $\begin{array}{l}\text { 2. Serious, } \\
\text { e.g., large abscess }\end{array}$ & $0(0.0)$ & - & - \\
\hline $\begin{array}{l}\text { 3. Significant, } \\
\text { e.g., pain, diarrhea }\end{array}$ & $0(0.0)$ & - & - \\
\hline \multirow{5}{*}{$\begin{array}{l}\text { 4. Moderate, } \\
\text { e.g., discomfort } \\
\text { or inconvenience } \\
\text { for } 1-24 \mathrm{~h}\end{array}$} & $5(2.5)$ & - Fracture missed on radiograph, called back & - \\
\hline & & $\begin{array}{l}\text { - Several stitches fell out, felt trainee was inadequately } \\
\text { supervised }\end{array}$ & - \\
\hline & & - Wound dressing "too large" and fell off, replaced in ED & - \\
\hline & & $\begin{array}{l}\text { - Patient mistakenly "discharged" from system before workup } \\
\text { complete }\end{array}$ & - \\
\hline & & $\begin{array}{l}\text { - Patient not contacted for follow-up CT scan as assured at } \\
\text { discharge, returned to ED }\end{array}$ & - \\
\hline $\begin{array}{l}\text { 5. Minor, } \\
\text { e.g., discomfort } \\
\text { or inconvenience } \\
\text { for }<1 \mathrm{~h}\end{array}$ & $2(1.0)$ & $\begin{array}{l}\text { - Patient mistaken for another patient with similar name } \\
\text { - Radiograph ordered for wrong limb }\end{array}$ & - \\
\hline$=$ emergency department. & & hird reviewer $n$ & err \\
\hline
\end{tabular}


members were recorded in the clinical record or hospital event reporting database by doctors and nurses. This is consistent with conclusions by Weingart and others that the underlying rate of adverse events is higher than that detected by any single approach., ${ }^{210-12}$ In a prospective, observational study in the ED of a tertiary care teaching hospital, Fordyce and colleagues ${ }^{13}$ identified an error rate of almost 1 per 5 patients, though $98 \%$ of the errors were not associated with adverse outcomes. Errors in this study occurred most commonly in diagnostic studies, followed by administration, pharmacotherapy, documentation communication and environmental maintenance. Policies of anonymous reporting are becoming prevalent in response to underreporting by health care providers, partly out of fear of repercussions. ${ }^{14,15}$ Leape $^{16}$ characterizes successful reporting systems as those that are nonpunitive, confidential, independent, provide expert analysis and timely feedback, are systems oriented and responsive. Anonymous, Web-based reporting systems offer convenience and anonymity and are thought to improve error reporting. ${ }^{17}$

Previously described error reduction techniques have included standardization of processes (adapting "critical pathways" and guidelines), formal teamwork training, ${ }^{18}$ minimizing interruptions,${ }^{19}$ increasing attention to the highrisk elements of health care (such as patient care transitions), introducing redundancy and resilience into systems,${ }^{20}$ and implementation of appropriate information technology (such as prescription order entry systems).
Lyons ${ }^{21}$ notes that while instituting patient reporting could potentially provide an extra barrier to error, problems are introduced by trying to account for the diversity of the patient and caregiver population, the heterogeneity of clinical areas and the potential for patient harm, and a loss of confidence in the health care system.

\section{Limitations}

Our study was performed as a convenience sample in $1 \mathrm{ED}$, and the results may not be generalizable to other institutions. We selected ambulatory patients who were not admitted to hospital and so were probably a healthier cohort than the general ED population. Although categorization of event severity was done by 1 trained rater, the potential for reviewer bias was limited by predefined criteria for categorization. Although patient recall bias was limited by the quick follow-up for first and second interview following discharge, the study methodology elicited reports of the patients' perceptions of errors, near misses and adverse events but did not seek to confirm whether such events occurred as described. Pre-established definitions of adverse events, errors and near misses do not eliminate the need for judgment. For example, a repeat visit for epistaxis was included in the judgment (i.e., after interview and chart review) that the patient may have been undermanaged and that this would be regarded as a treatment error. While we expected that the methodology would not capture all

\begin{tabular}{|c|c|c|c|c|}
\hline $\begin{array}{l}\text { Type of process problem; } \\
n=201 \text { surveyed }\end{array}$ & $\begin{array}{l}\text { Adverse event; } \\
\quad n=10(5 \%)\end{array}$ & $\begin{array}{l}\text { Near miss; } \\
n=8(4 \%)\end{array}$ & $\begin{array}{l}\text { Medical error; } \\
\quad n=0(0 \%)\end{array}$ & $\begin{array}{c}\text { Total; } \\
n=18(9 \%)\end{array}$ \\
\hline \multicolumn{5}{|l|}{ Diagnosis-related problems } \\
\hline Diagnosis error & - & 1 & - & 1 \\
\hline \multicolumn{5}{|l|}{ Medication-related problems } \\
\hline Inadequate monitoring or follow-up & 1 & - & - & 1 \\
\hline Failure to order & 5 & - & - & 5 \\
\hline Inappropriate choice of drug & - & 1 & - & 1 \\
\hline \multicolumn{5}{|l|}{ Procedure-related problems } \\
\hline Procedure-related error & 1 & - & - & 1 \\
\hline Postprocedure-related error & 1 & 2 & - & 3 \\
\hline \multicolumn{5}{|l|}{ Clinical services problems } \\
\hline Wrong patient & - & - & - & - \\
\hline Improper supervision & 1 & - & - & 1 \\
\hline $\begin{array}{l}\text { Test or procedure performed on wrong } \\
\text { body part }\end{array}$ & - & 1 & - & 1 \\
\hline $\begin{array}{l}\text { Failure to perform or delayed } \\
\text { performance of test or procedure }\end{array}$ & 1 & - & - & 1 \\
\hline \multicolumn{5}{|l|}{ Service quality problems } \\
\hline Lost order or chart & - & 3 & - & 3 \\
\hline Waits and delays & - & - & - & - \\
\hline Problems with environment & - & - & - & - \\
\hline
\end{tabular}


events that occurred within 7 days of discharge, and none after that point, we note that all events identified occurred within 72 hours of ED discharge.

\section{Conclusion}

It is likely that many errors, near misses and adverse events go unnoticed by health care providers. In our study, most adverse events were preventable and clustered around a specific process (pain management). Interviewing patients and their family members may serve a useful role in identifying errors and process of care deficiencies.

Competing interests: None declared.

\section{References}

1. Adams JG, Bohan JS. System contributions to error. Acad Emerg Med 2000;7:1189-93.

2. Weingart SN, Pagovich O, Sands DZ, et al. What can hospitalized patients tell us about adverse events? J Gen Intern Med 2005;20:830-6.

3. Forster AJ, Murff HJ, Peterson JF, et al. The incidence and severity of adverse events affecting patients following discharge from the hospital. Ann Intern Med 2003;138:161-7.

4. Forster AJ, Clark HD, Menard A, et al. Adverse events affecting medical patients following discharge from hospital. CMAJ 2004;170:345-9.

5. Burroughs TE, Waterman AD, Gallagher TH, et al. Patient concerns about medical errors in emergency departments. Acad Emerg Med 2005;12:57-64.

6. Forster AJ, Rose NGW, Walraven CV, et al. Adverse events following an emergency department visit. Qual Saf Health Care 2007; 16:17-22.

7. Gandhi TK, Weingart SN, Peterson J, et al. Adverse drug events in ambulatory care. N Engl J Med 2003;348:1556-64.

8. Joint Commission for Accreditation of Healthcare Organizations. Comprehensive accreditation manual for hospitals: the official handbook. Joint Commission Accreditation Healthcare
Organizations. Oakbrook Terrace (IL): The Organization; 2006.

9. Pines JM, Hollander JE. Emergency department crowding is associated with poor care for patients with severe pain [discussion 6-7]. Ann Emerg Med 2008;51:1-5.

10. Leape LL. Error in medicine. JAMA 1994;272:1851-7.

11. Cullen DJ, Bates DW, Small SD, et al. The incident reporting system does not detect adverse drug events: a problem for quality improvement. JT Comm J Qual Improv 1995;21:541-52.

12. Taylor JA, Brownstein D, Christakis DA, et al. Use of incident reports by physicians and nurses to document medical errors in pediatric patients. Pediatrics 2004;114:729-35.

13. Fordyce J, Blank FSJ, Pekow P, et al. Errors in a busy emergency department. Ann Emerg Med 2003;42:324-33.

14. Vincent C, Stanhope N, Crowley-Murphy M. Reasons for not reporting adverse incidents: an empirical study. J Eval Clin Pract 1999;5:13-21.

15. Lawton R, Parker D. Barriers to incident reporting in a healthcare system. Qual Saf Health Care 2002;11:15-8.

16. Leape LL. Reporting of adverse events. N Engl J Med 2002; 347:1633-8.

17. Khare RK, Uren B, Wears RL. Capturing more emergency department errors via an anonymous web-based reporting system. Qual Manag Health Care 2005;14:91-4.

18. Morey JC, Simon R, Jay GD, et al. Error reduction and performance improvement in the emergency department through formal teamwork training: evaluation results of the MedTeams project. Health Serv Res 2002;37:1553-81.

19. Elinson R, Friedman SM. Emergency Physician Time and Motion Study. Acad Emerg Med 2004;11:457-b-458.

20. Wears RL. A different approach to safety in emergency medicine. Ann Emerg Med 2003;42:334-46.

21. Lyons M. Should patients have a role in patient safety? A safety engineering view. Qual Saf Health Care 2007;16:140-2.

Correspondence to: Dr. Steven Marc Friedman, Toronto General Hospital, 200 Elizabeth St., Toronto ON M5G 2C4; steven.friedman@utoronto.ca

\section{IMPORTANT ANNOUNCEMENT!}

CJEM is moving its submission and tracking system to Manuscript Central (Scholar One) and we plan to begin accepting submissions around the end of September or the beginning of October. More information and updates can be found on our website at www.cjem-online.ca. 